\title{
La masonería en el Territorio Nacional de Neuquén (Argentina): el caso de las logias "Obre- ros Luz del Neuquén” y "La Verdad"
}

\section{Freemasonry in the National Territory of Neuquén (Argentina): the case of the "Obreros Luz del Neuquén" and "La Verdad" lodges}

\author{
Mariana Annecchini \\ Universidad Nacional de La Pampa, Argentina \\ mariannecchi@hotmail.com
}

Recepción: 30 de marzo de 2019/Aceptación: 2 de julio de 2019

doi: https://doi.org/10.15517/rehmlac.v11i2.36807

\section{Palabras clave}

Argentina; masonería; Territorio Nacional de Neuquén; “Obreros Luz del Neuquén”; "La Verdad”.

\section{Keycords}

Argentina, Freemasonry, Neuquén National Territory, “Obreros Luz del Neuquén”, "La Verdad”.

\section{Resumen}

En este trabajo estudiamos dos logias del Territorio Nacional de Neuquén, Argentina, a comienzos del siglo XX: "Obreros Luz del Neuquén” y "La Verdad". Nuestro objetivo es indagar su origen; su funcionamiento; sus disputas y sus tensiones internas. También aportamos evidencia de las redes de vinculación entre los masones y el poder político al formarse los territorios nacionales. Así, nos proponemos a contribuir al estudio de un tema complejo desde una perspectiva académica alejada de miradas filosóficas o de rituales. Para el abordaje del problema trabajamos con material documental escrito, específicamente los expedientes de las dos logias masónicas analizadas.

\begin{abstract}
In this paper we study two lodges in the National Territory of Neuquén, Argentina, at the beginning of the 2oth century: "Obreros Luz del Neuquén" and "La Verdad". Our objective is to research the lodges and the networks of Freemasons within the political local, territorial and national power. Providing thus, evidence of the role Masonic lodges played in the formation of new national territories. Our aim is to study this complex topic from an academic perspective in order include the associative practices of Freemasons, that comprised political identities. Our sources have been the archives of both masonic lodges.
\end{abstract}




\section{Introducción}

Las logias masónicas proliferaron en Argentina en la década de 1850 en un contexto de "impulso" o "explosión asociativa". ${ }^{1}$ Entre las múltiples formas de asociacionismo que se desarrollaron luego de 1852, la masonería y las instituciones derivadas de ella (organizaciones laicas dedicadas a la asistencia pública y a la educación) ocuparon un lugar de preferencia, y se convirtieron en ámbitos privilegiados de la esfera pública moderna²

Los territorios nacionales fueron uno de los espacios donde el asociacionismo masón no solo se desarrolló, sino que sus principales exponentes mediaron entre la sociedad civil y el poder político3. De acuerdo a lo estudiado por Bandieri para el caso del Territorio Nacional de Neuquén, las logias masónicas se convirtieron en un camino válido para el acceso a cargos políticos y directivos en la administración pública de los territorios, así como también para la generación y el fortalecimiento de vínculos comerciales y económicos que les permitieron a sus miembros llevar adelante importantes negocios ${ }^{4}$. Desde la perspectiva de la autora, las incipientes poblaciones patagónicas, sobre todo las que fueron asiento de las nuevas autoridades territorianas, ofrecieron alternativas válidas para consolidar redes sociales de carácter laico y liberal, como la masonería. Estas formas asociativas tuvieron un fuerte arraigo en las "sociedades nuevas", lo cual les permitió una mayor apropiación del espacio público local y regional. En el territorio de Neuquén sabemos de la existencia de dos logias que iniciaron sus actividades en los inicios del siglo XX: "Obreros Luz del Neuquén” y "La Verdad”. El Territorio Nacional de La Pampa también vio emerger en el mismo periodo varias logias cuya influencia fue prominente hasta aproximadamente mediados del siglo $\mathrm{XX}^{5}$. Es decir, en ambos territorios patagónicos las logias se desarrollaron como parte de un movimiento mayor que involucró a las diferentes provincias y territorios argentinos. En este artículo estudiamos las logias “Obreros Luz del Neuquén” y "La Verdad”. El objetivo es indagar su origen, composición, funcionamiento, las divisiones y tensiones internas,

$1 \quad$ Inicialmente estuvieron integradas por extranjeros y en 1856 se conformaron las primeras tres logias integradas mayoritariamente por argentinos, dos en Buenos Aires y otra en la Confederación. A partir de 1862 el surgimiento de logias se aceleró en todo el país producto de la atracción que ejerció sobre comerciantes, funcionarios, grandes propietarios, profesionales, intelectuales y militares. En su origen todas dependieron del Gran Oriente de la República del Uruguay, donde la masonería se desarrolló más tempranamente que en Argentina. Roberto Di Stefano, "La expulsión de los masones", en Ovejas negras: Historia de los anticlericales argentinos (Buenos Aires: Sudamericana, 2010), p. 197.

2 Pilar González Bernaldo, Civilidad y política en los orígenes de la Nación Argentina. Las sociabilidades en Buenos Aires, 1829-1862 (Buenos Aires: Fondo de Cultura Económica, 2001).

3 Luego de la denominada “Conquista del desierto", el régimen liberal de 188o, bajo la presidencia de Julio Argentino Roca, buscó establecer un ordenamiento político y social en las "nuevas" tierras conquistadas al indio. Dicho orden político adquirió legitimidad en 1884 cuando se dictó la Ley $\mathrm{N}^{\circ} 1532$ de creación de Territorios Nacionales, que dio vida institucional a las tierras recién incorporadas a la República Argentina. Por esta norma, se delimitaron y organizaron los territorios nacionales de Misiones, Formosa, Chaco, La Pampa, Neuquén, Río Negro, Chubut, Santa Cruz y Tierra del Fuego. La Ley de Territorios Nacionales, entonces, dio origen a nuevas áreas en los márgenes de las provincias históricas, que habían estado bajo el dominio de diversas parcialidades indígenas. Las nuevas unidades administrativas no tuvieron las mismas prerrogativas que las provincias y dependieron de modo directo del Poder Ejecutivo Nacional, que se ocupó del nombramiento de funcionarios, reparto de tierras y recaudación de la renta. Susana Bandieri, "Ampliando las fronteras. La ocupación de la Patagonia”, en El progreso, la modernización y sus límites (1880-1916), dir. Mirta Zaida Lobato (Buenos Aires: Sudamericana, 200o), 119-178.

4 Bandieri, La masonería en la Patagonia, 36.

5 En el territorio nacional de la Pampa se sabe de la existencia de seis logias creadas en las primeras décadas del siglo XX. Ellas son: "Luz de la Pampa”, "Estrella de La Pampa”, “Independencia de La Pampa No 303”, "Independencia Argentina”, "Libertad” y "Triángulo Luz de La Pampa”. Ana María T. Rodríguez, "Masones en el interior argentino: su funcionamiento, sus redes de vinculación y su disidencia religiosa (1907-1924)", REHMLAC+ 9, no. 2, (diciembre 2017-mayo 2018): 176-193, https://doi.org/10.15517/rehmlac.v9i2.29481 
así como las redes de vinculación que los masones tejieron con el poder político, local, territoriano y nacional, como forma de aportar evidencia acerca del papel que las logias masónicas desempeñaron dentro de la sociedad civil en el contexto de formación de los territorios nacionales.

Partimos de la consideración de que las logias masónicas jugaron un papel relevante dentro de la sociedad civil, sus miembros construyeron redes de sociabilidad, se integraron en instituciones clave en la toma de decisiones y desde estos ámbitos generaron estrechos lazos con grupos de poder e influencia política y económica. A partir de aquí intentaron contribuir a la puesta en marcha de un país acorde con las ideas del liberalismo laicista. Desde esta perspectiva, nos proponemos contribuir al estudio de un tema complejo con una mirada académica que sea capaz de reconocer otros componentes y categorías conceptuales en el estudio de la masonería, a saber: su configuración como ámbito de sociabilidad, las prácticas asociativas de los masones y su incidencia en el espacio público local, así como el proceso de conformación de identidades políticas.

Como es sabido, el estudio de la masonería es complejo en su etapa investigativa y es necesario hacer una rigurosa selección crítica de la historiografía sobre el tema. En esta investigación destacamos aquellas líneas teóricas que, lejos de reducir el estudio de la masonería a una historia de mitos y leyendas, abordan el tema con rigor científico y se proponen recuperar otros elementos, como su componente histórico y socio político. El historiador español José Antonio Ferrer Benimeli constituye el principal referente en la materia y fue el pionero en abordar la historia de la masonería desde la perspectiva de diferentes continentes, especialmente entre Europa y América ${ }^{6}$. En uno de sus trabajos, "Aproximación a la historiografía de la masonería latinoamericana", el autor nos ofrece un análisis exhaustivo sobre las principales investigaciones que estudian el tema en México, Centroamérica y América del Sur. En este sentido, sus investigaciones se constituyen en una referencia obligada para quienes investigan la masonería en el contexto latinoamericano y caribeño ${ }^{7}$.

En América Latina las producciones académicas que presentan una visión más crítica y reflexiva de la masonería se pueden enmarcar, según Ferrer Benimeli, en un clima de renovación historiográfica que cobró fuerza en el marco de las celebraciones bicentenarias de las independencias americanas y vinieron a reemplazar el predominio de los ensayos de tipo filosófico, ritualístico y mistérico-esotérico ${ }^{8}$. En este contexto, en los últimos años, el

6 Yván Pozuelo Andrés, "Migraciones", en Masonería y Masones. Tomo I. Migraciones, eds. Ricardo Martínez Esquivel, Pozuelo Andrés y Rogelio Aragón (Ciudad de México: Palabra de Clío, 2017), 6-9.

$7 \quad$ Dentro de la importante laborar desarrollada por Ferrer Benimeli es relevante destacar la creación, en 1983, del Centro de Estudios Históricos de la Masonería Española (CEHME) de la Universidad de Zaragoza, España. Dicha institución aglutina a investigadores procedentes de diferentes ramas de las ciencias sociales, que se ocupan de producir estudios relativos a la masonería europea en su relación con América. Desde la fecha de su creación, el CEHME convoca regularmente reuniones científicas en las cuales numerosos investigadores nacionales y extranjeros realizan aportes a la historiografía de la masonería desde el siglo XVIII hasta el presente. Como resultado de dichos encuentros se han publicado hasta el momento 27 volúmenes de Actas que recogen las investigaciones presentadas. De esta manera, la historia de la masonería elaborada desde el CEHME constituye una referencia nacional e internacional.

8 Ferrer Benimeli explica que las celebraciones bicentenarias de las independencias americanas permitieron un proceso de revisión de la historia liderado por universidades, academias, centros de investigación y culturales 
tema comenzó a ser estudiado por un grupo de investigadores académicos que se propusieron recuperar la memoria histórica de la masonería y de los masones. Así, la labor iniciada por Ferrer Benimeli vinculada a promover los estudios sobre la masonería en Latinoamérica, fue continuada por el historiador cubano Eduardo Torres-Cuevas, quien en 2007 organizó el grupo La Habana, la primera red académica de investigadores de la masonería. Sin duda, los aportes historiográficos provenientes de los nuevos enfoques contribuyen a revisar, comprender y reinterpretar la historia de la masonería y de los masones.

En el ámbito académico argentino no abundan las investigaciones sobre el tema y el estudio de la masonería ha sido incorporado en las agendas de algunos historiadores específicos, tales como: Pilar González Bernaldo, Carlos Mayo, Marta Bonaudo, Susana Bandieri, Ana Rodríguez, Dévrig Mollés, entre algunos de los principales. Además, debemos destacar los estudios pioneros de Albicíades Lappas y del escritor y periodista Emilio Corbiére $^{9}$. Estos trabajos contemplan una serie de aspectos que van desde los orígenes de la masonería, sus vínculos con la esfera política, las tensiones y divisiones en su interior, las acciones concretas de sus protagonistas, como la organización de los congresos de librepensamiento, hasta el desarrollo e influencia de la masonería en los territorios nacionales de Argentina. Como señalamos anteriormente, este artículo analiza la dinámica de dos logias que funcionaron en el Territorio Nacional de Neuquén en el contexto de construcción de su institucionalidad política, económica y social. En este sentido, constituye un aporte a la historiografía de la masonería en Argentina y, de manera particular, a los estudios del tema que se centran en el ámbito territoriano.

Para el abordaje del problema trabajamos con material documental escrito, inédito, específicamente expedientes de las dos logias masónicas analizadas. La documentación,

que propiciaron una proliferación de encuentros, congresos, simposios, seminarios y publicaciones. Paralelamente, en las últimas décadas se fue consolidando una visión más crítica en la mayor parte de los estudiosos e investigadores de todas las tendencias gracias al avance de la interdisciplinariedad y al recurso a fuentes primarias documentales y hemerográficas hasta hace unos años desconocidas o poco utilizadas. La historia de la masonería no fue ajena a esta revisión y reelaboración. José Antonio Ferrer Benimeli, "Aproximación a la historiografía de la masonería latinoamericana”, REHMLAC 4, no. 1 (mayo -noviembre 2012): 9, https://revistas.ucr. ac.cr/index.php/rehmlac/article/view/12144/11419

9 González Bernaldo, "Masonería y Nación: la construcción masónica de una memoria histórica nacional”, Historia 25, Revista del Instituto de Historia (1990): 81-101. Carlos Mayo, "La masonería en crisis (1902-1922)", en Conflictos y Procesos de la Historia Argentina Contemporánea, tomo 5 (Buenos Aires: Centro Editor de América Latina, 1988). Marta Bonaudo, “Liberales, masones ¿subversivos?”, Revista de Indias LXVII (2007): 403-432. Marta Bonaudo, “Sociabilidades que construyen repúblicas? los desafíos de la masonería decimonónica mirados desde algunos espacios santafesinos y entrerrianos", en Descubriendo la nación: identidades, imaginarios, estereotipos sociales y formas de asociacionismo de los españoles en el Cono Sur de América, comps. Elda González y Andrea Reguera (Buenos Aires: Biblos, 2010), 45-67. Susana Bandieri, "Sociedad civil y redes de poder social en los territorios nacionales del sur: Neuquén, Patagonia, Argentina 1880-1907”, Boletín Americanista 57 (2007): 53-68. Susana Bandieri, "La masonería en la Patagonia. Modernidad liberal y asociacionismo masón en Neuquén (1884-1907)", Estudios Sociales, 38 (primer semestre 2010): 9-38, https://doi.org/10.14409/es.v38i1.2652. Rodríguez, “¿Quiénes eran los masones pampeanos de principios de siglo XX? Un estudio de su perfil socio ocupacional y sus redes de vinculación” (Ponencia presentada en el Segundo Seminario euro-argentino de historia de las redes masónicas atlánticas, Buenos Aires, 22-23 de mayo 2014), http://www.redalyc.org/pdf/3695/369537363010.pdf. Rodríguez, "Los masones pampeanos de principios del siglo XX: el perfil socio ocupacional y las redes de vinculación de la Logia $L u z d e$ La Pampa, General Pico (1909-1914)" (Ponencia presentada en las XXII fornadas de Investigación de la Facultad de Ciencias Humanas, Santa Rosa, La Pampa, 10-11 setiembre 2015). Dévrig Mollés, La invención de la masonería. Revolución cultural: religión, ciencia y exilios (La Plata: EDULP, 2015); Albicíades Lappas, La masonería argentina través de sus hombres (Buenos Aires: Ediciones masónicas, 1966 [1958]; Lappas, La Masonería en la ocupación del desierto (Buenos Aires: Instituto Histórico de la Organización Nacional, 1981). Emilio Corbiére, La masonería II: tradición y revolución (Buenos Aires: Debolsillo, 2007 [2001]); Corbiére, La masonería: política y sociedades secretas (Buenos Aires: Debolsillo, 2011 [1998]). 
que abordamos desde una perspectiva cualitativa, procede del Archivo de la Gran Logia Argentina y permite realizar una identificación nominal de los actores estudiados, así como también reconstruir parte de la trama de relaciones sociales e institucionales que desarrollaron los masones del Territorio Nacional de Neuquén durante los primeros años del siglo $\mathrm{XX}^{10}$.

\section{Logia “Obreros Luz del Neuquén”}

Tal como se pudo observar en la introducción, el estudio de la masonería en Neuquén ha sido tratado en diversos trabajos por la historiadora Susana Bandieri. De manera concreta, en un artículo del año 2013 la investigadora abordó el caso de la Logia "Obreros Luz del Neuquén”" ${ }^{11}$ Dicho estudio resulta relevante para conocer las características de la institución y de sus integrantes, así como su funcionamiento y las redes tejidas por la masonería local en el ámbito territoriano y nacional. Este artículo intenta aportar nuevos datos empíricos a partir del acceso al expediente original de la logia ${ }^{12}$.

\section{Creación de la logia}

El 10 de enero de 1905 se formó en Neuquén, capital del territorio, el Triángulo "Obreros Luz del Neuquén $\mathrm{N}^{\circ} 95$ ", perteneciente al Rito Azul. Una vez constituido, los miembros fundadores solicitaron los auspicios al Gran Consejo del Gran Oriente Argentino del Rito Azul. De la primera elección de dignatarios resultaron electos el marino Antonio Natali y los militares Ireno Banchs y Justo Emegar Urquiza. Los tres se desempeñaban como miembros activos de otras logias nacionales, lo que refleja que se trataba de personas con experiencia previa en la masonería.

\section{Cuadro 1. Resultado de la primera elección de autoridades}

\begin{tabular}{l|c|c|c|c|c|c|c|}
$\begin{array}{l}\text { NOMBRE } \\
\text { CARGO }\end{array}$ & GRADO & NACIONALIDAD & $\begin{array}{c}\text { ESTADO } \\
\text { CIVIL }\end{array}$ & PROFESIÓN & EDAD & $\begin{array}{c}\text { PERTENENCIA A OTRAS } \\
\text { LOGIAS }\end{array}$ \\
$\begin{array}{l}\text { Antonio } \\
\text { Natali }\end{array}$ & Presidente & 3 & Italiano & Soltero & Marino & 33 & $\begin{array}{l}\text { Miembro activo y cotizante de } \\
\text { la logia } 1^{\circ} \text { Argentina }\end{array}$ \\
$\begin{array}{l}\text { Ireneo } \\
\text { Blanchs }\end{array}$ & Secretario & 3 & Argentino & Soltero & Militar & 24 & $\begin{array}{l}\text { Miembro activo y cotizante de } \\
\text { la logia Libertad }\end{array}$ \\
$\begin{array}{l}\text { Justo E. } \\
\text { Urquiza }\end{array}$ & Tesorero & 3 & Argentino & Soltero & Militar & 26 & $\begin{array}{l}\text { Miembro activo y cotizante de } \\
\text { la logia Esperanza }\end{array}$
\end{tabular}

Elaboración propia con base en el expediente de la Logia “Obreros Luz del Neuquén”. Archivo de la Gran Logia Argentina (en adelante AGLA), Buenos Aires, Argentina.

10 Es importante aclarar que el expediente de la logia "La Verdad” es más reducido en comparación al expediente de la Logia "Obreros Luz del Neuquén". Por tal motivo, se dificultó reconstruir algunos datos, tales como, la cantidad de miembros de la Logia, su perfil social y etario, la procedencia de los mismos, así como la fecha en la cual la institución dejó de funcionar.

11 Bandieri y Marisa Moroni, "Prácticas asociativas seculares, poder y política: masones en Neuquén y espiritistas en La Pampa en la primera mitad del siglo XX", en Estudios de Historia Religiosa argentina (siglos XIX y XX), ed. Rodríguez (Rosario: Prohistoria ediciones, 2013), 85-106.

12 Va en estas páginas un agradecimiento especial a Dévrig Mollés, director del Archivo de la Gran Logia Argentina, y al personal de la institución por haberme recibido de manera cordial y permitido relevar sin ningún tipo de restricción el material perteneciente a las logias que aquí presento. 
El 1 de junio de 1905 el Ven. Maestro Eduardo Talero comunicó que de acuerdo con las atribuciones conferidas por el Gran Oriente se procedería a erigir el Triángulo "Obreros Luz del Neuquén” en logia regulary perfecta bajo los auspicios del Rito Azul; por lo tanto, se debía proceder a la elección de autoridades. Seguidamente y por votación secreta emitieron los sufragios los masones asistentes. De la votación resultaron electas las siguientes personas, quienes, además, figuran en el acta como hermanos fundadores de la Logia "Obreros Luz del Neuquén".

\section{Cuadro 2. Resultado de la elección de autoridades. Año 1905}

\begin{tabular}{|c|c|c|c|c|c|c|c|}
\hline NOMBRE & CARGO & GRADO & NACIONALIDAD & $\begin{array}{l}\text { ESTADO } \\
\text { CIVIL }\end{array}$ & PROFESIÓN & EDAD & DOMICILIO \\
\hline $\begin{array}{l}\text { Eduardo } \\
\text { Talero }\end{array}$ & Ven. Maestro & 3 & Argentino & Soltero & Abogado & 34 & Neuquén \\
\hline José Vallhonrat & $1^{\circ}$ Vig. & 3 & Español & Casado & Contratista & 46 & Neuquén \\
\hline Augusto Grobly & $2^{\circ}$ Vig. & 3 & Argentino & Casado & Comerciante & 33 & Neuquén \\
\hline Joaquín Gréz & Secretario & 3 & Español & Soltero & $\begin{array}{c}\text { Profesor y } \\
\text { Farmacéutico }\end{array}$ & 31 & Neuquén \\
\hline $\begin{array}{l}\text { Ferruccio } \\
\text { Verzegnassi }\end{array}$ & Orador & 3 & Austrohúngaro & Soltero & Farmacéutico & 30 & Neuquén \\
\hline Andrés Imperiale & Tesorero & 3 & Italiano & Soltero & Farmacéutico & 28 & Neuquén \\
\hline $\begin{array}{l}\text { Domingo } \\
\text { Mazzoni }\end{array}$ & Hospitalario & 3 & Italiano & Casado & Industrial & 47 & Neuquén \\
\hline Tomás Martinez & $\begin{array}{l}\text { Maestro de } \\
\text { Ceremonias }\end{array}$ & 3 & Argentino & Soltero & Empleado & 29 & $\begin{array}{l}\text { Plaza Huincó } \\
\left(\mathrm{TNN}^{13}\right)\end{array}$ \\
\hline $\begin{array}{l}\text { José Luis Moris } \\
\text { Giménez }\end{array}$ & Aprendíz & & Argentino & Viudo & $\begin{array}{c}\text { Empleado } \\
\text { nacional }\end{array}$ & 34 & Cholila $\left(\mathrm{TNCH}^{14}\right)$ \\
\hline $\begin{array}{l}\text { Emilio Rodríguez } \\
\text { Iturbide }\end{array}$ & Aprendiz & & Chileno & Soltero & $\begin{array}{c}\text { Empleado } \\
\text { nacional }\end{array}$ & 22 & Neuquén \\
\hline
\end{tabular}

Elaboración propia con base en el expediente de la Logia “Obreros Luz del Neuquén”.

\section{AGLA, Buenos Aires, Argentina.}

Conformada la Logia, se debía resolver el tema del lugar donde sesionar. Fue así que el mismo día del pase de Triángulo a Logia el $1^{\circ}$ Vig. José Vallhonrat pidió la palabra y se refirió a la falta de un espacio adecuado donde reunirse, dando paso seguidamente a la votación de una comisión pro-templo. La misma quedó conformada por Domingo Mazzoni, José Vallhonrat y Joaquín Gréz. Del mismo modo se aceptaron los ofrecimientos de Andrés Imperiale y Joaquín Gréz, el primero acerca de un local para instalar interinamente el templo y el segundo para proporcionar gratuitamente los útiles de trabajo más indispensables.

Sobre la obtención de la personería jurídica, el 11 de julio de 1906 los masones dirigieron una correspondencia al secretario general, Pedro Grande, para expresar el deseo de contar con la personería jurídica y solicitar se les informe qué tramites debían iniciar para conseguirla ${ }^{15}$. Obtenida la información, comunicaron que pronto iniciarían las tareas correspondientes para su ejecución.

13 Territorio Nacional de Neuquén.

14 Territorio Nacional de Chubut.

15 Pedro Grande era un italiano que, junto con sus hermanos Salvador (platero) y Rosario (grabador), eran propietarios de una de las más importantes joyerías de la ciudad de Buenos Aires. Bandieri y Moroni, Prácticas asociativas, 96. 


\section{Composición}

Según registra el acta, la Logia a poco de su formación comenzó a recibir pedidos de iniciación y afiliación. Sin embargo, en sus inicios los dignatarios se refirieron a un taller reducido y con grandes gastos diarios que se seguirían originando hasta lograr poner al taller en perfecto y completo estado de funcionamiento. Por este motivo, pusieron a consideración eliminar la obligación que tenía la logia de enviar al Gran Oriente un censo anual con la cantidad de miembros. De acuerdo a los datos aportados por la documentación, las solicitudes de ingreso entre los años 1905 y 1907 no superaron las 50 personas. Un censo del periodo 1906-1907 registrado en actas aportó como dato la existencia de un total de 14 miembros activos y cotizantes. Mientras que para el 1 de julio de 1907 la lista de "hermanos que conformaban la logia” sumó $16^{16}$. Es así que la preocupación por el escaso número de integrantes fue un tema recurrente en las sesiones. El Ven. Maestro Domingo Mazzoni expresó al respecto:

...Con estas ausencias ha venido a disminuir el número de obreros de este Taller y estamos expuestos a que disminuya más y quedemos sin número legal, pues siendo la mayoría de los hnos. empleados sucede con frecuencia que tienen que cambiar de domicilio por causa y comisiones de los puestos que desempeñan...Tratamos de investigar y de elegir con rigurosa atención el elemento que mejor y más digno nos parece para formar parte de nuestras filas, que dicho sea de paso es de advertir que es muy escaso en estos lugares desiertos en donde vienen a residir por lo general toda clase de aventureros... ${ }^{17}$

Además de la preocupación manifiesta por la disminución de los miembros, la cita refleja el interés de las autoridades en sumar miembros a una institución recién fundada, en una ciudad también en construcción donde todo estaba por hacerse. Asimismo, las palabras de Mazzoni arrojan luz sobre el perfil socio-ocupacional predominante en el interior de la institución y sobre los posibles criterios de selección al momento de sumar nuevos integrantes.

Con respecto al origen de los miembros, podemos decir que la actividad de la Logia fue propiciada y desarrollada por argentinos y por migrantes externos, tal como se evidencia en el cuadro $\mathrm{N}^{\circ}$ 2. En las solicitudes de ingreso se destaca la presencia de argentinos, seguidos por españoles, italianos y una minoría de otras nacionalidades. El predominio de miembros de nacionalidad argentina seguidos por españoles e italianos se corresponde con el proceso poblacional del Territorio. Tal como lo han estudiado Manara y Fernández, durante el proceso de inmigración masiva a la Argentina el Territorio Nacional de Neuquén cumplió el rol de espacio receptor de población extranjera. El caso de los inmigrantes italianos y españoles resulta singular en la historia del poblamiento territoriano porque, si bien fueron significativamente mayoritarios dentro de los grupos europeos, en la conformación general de la población local constituyeron minorías con relación a la población argentina y chilena. ${ }^{18}$ Sin embargo, conviene diferenciar el alcance de estos grupos étnicos en la ciudad

$\overline{16}$ Acta de la Logia "Obreros Luz del Neuquén”, 1 de julio de 1907. AGLA, Buenos Aires, Argentina.

17 Acta de la Logia "Obreros Luz del Neuquén", 10 de febrero de 1906. AGLA, Buenos Aires, Argentina.

18 El censo nacional de 1895 registra una presencia mayoritaria de población chilena, seguida por la población 
de Neuquén y en el resto del Territorio. En el seno de la sociedad neuquina los italianos y españoles, siendo cuantitativamente minorías, fueron sujetos de constante movilización. En palabras de las autoras, la participación de estos inmigrantes en las distintas actividades del quehacer local les permitió un alto grado de inserción. En cambio, el interior del Territorio se caracterizó por la ocupación precaria e ilegal de la tierra por una móvil población chilena que generó una serie de conflictos con el gobierno central. Estas diferencias dieron como resultado un interior relegado con una marcada relación económica y cultural con Chile, frente al gradual crecimiento que logró el Departamento Confluencia y en cuya expansión fue esencial el rol ejercido por los italianos y españoles ${ }^{19}$. Estos datos contribuyen a comprender, como se puede observar en el cuadro 3, la casi nula presencia de chilenos en la Logia, pese a que era la población mayoritaria según el censo nacional de $1895^{20}$.

\section{Cuadro 3. Nacionalidad de los integrantes de la Logia}

\begin{tabular}{c|c} 
NACIONALIDAD & TOTALES \\
Argentina & 22 \\
Extranjeros & 23 \\
\hline Española & 11 \\
Italiana & 7 \\
Cubana & 1 \\
Chilena & 1 \\
Rusa & 2 \\
Turca & 1
\end{tabular}

argentina, española e italiana. Asimismo, puede observarse que estos grupos europeos, especialmente el español, tendieron a asentarse en el Departamento Confluencia, que tenía como núcleo urbano principal a la ciudad de Neuquén. En el censo de 1914, a una década de la capitalización de Neuquén, se detectan algunos cambios. Si bien la población chilena aumentó a nivel territorial fue superada por un significativo crecimiento demográfico de la población argentina. En eı caso del Departamento Confluencia es más notable la merma del porcentaje de chi1enos que el aumento de residentes argentinos. Con respecto a los españo1es e italianos se registró un importante aumento cuyo mayor índice siguió concentrándose en el núcleo urbano de Neuquén. En el censo de 1920 no se observan cambios esenciales en la composición y distribución de la población a no ser un leve aumento de argentinos, españoles e italianos y una disminución general de extranjeros chilenos. Cabe destacar que los españoles ocupaban el segundo lugar en la composición general de la población del Departamento Confluencia. Comparando los tres censos analizados puede constatarse fácilmente que la población de procedencia española fue superior a la de procedencia italiana lo que resulta singular si consideramos que por esos años la entrada masiva de inmigrantes al país era predominantemente itaiiana. Carla Manara y Sonia Fernández, "La problemática inmigratoria en Neuquén: españoles e italianos (1895-1930), en Historia de Neuquén, ed. Bandieri, Orietta Favaro, Marta Morinelli, Susana Rodríguez, Gladys Varela y otros (Neuquén: Plus Ultra, 1993), 263-283, http://cehepyc. uncoma.edu.ar/archivos/1993-HISTORIA\%20NEUQUEN.pdf

19 El Departamento Confluencia constituyó un polo de atracción para el asentamiento de estos grupos étnicos que desarrollaron y diversificaron las posibiiidades que les brindaron estas tierras poco aptas para la ganadería, pero favorables para la agricultura extensiva, la extracción de hidrocarburos y especialmente para la iniciativa privada en actividades vinculadas a la rama terciaria. Manara y Fernández, La problemática inmigratoria, 272.

20 El Censo nacional de 1895 registró una población de 14.517 habitantes para el Territorio Nacional de Neuquén, de los cuales el $63 \%$ eran extranjeros, la mayoría chilenos.

En el caso de la Logia "Rivadavia", del Territorio Nacional de Santa Cruz, la historiadora Aixa Bona también observa la escasa presencia de chilenos pese a que representaban el $20 \%$ de los censados en el año 1920. Según afirma la autora, la razón posible de dicha ausencia estaría dada en que buena parte de la población chilena también era móvil, se trataba fundamentalmente de trabajadores migrantes de las estancias y el frigorífico, sectores que no fueron ámbitos de reclutamiento de la Logia. Aixa Bona, "La Logia Rivadavia en el Territorio de Santa Cruz. 1920-1944" (ponencia presentada en las zas fornadas de Historia de la Patagonia, San Carlos de Bariloche, 6-8 de noviembre 2008), http://www.hechohistorico.com.ar/Trabajos/Jornadas\%20de\%20Bariloche\%20-\%202008/Bona.pdf 
Elaboración propia con base en el expediente de la Logia “Obreros Luz del Neuquén”,

AGLA, Buenos Aires, Argentina.

A su vez, el influjo de miembros de nacionalidad española e italiana en el interior de la Logia tiene vinculación con el protagonismo que esos grupos étnicos tuvieron en la ciudad de Neuquén. Según afirman Manara y Fernández, españoles e italianos constituyeron una fuerza social significativa en el proceso de formación de la ciudad. De manera concreta, desempeñaron un papel significativo en el ámbito económico-laboral, así como también a nivel cultural, social y político, incluso con anterioridad a la fundación de la capital en $1904^{21}$. La participación en los distintos niveles del quehacer local les permitió insertarse rápidamente en la sociedad neuquina, siendo partícipes del proceso de formación de la ciudad al mismo tiempo que tuvieron alternativas de progreso y ascenso social ${ }^{22}$.

Con respecto al perfil socio-ocupacional de quienes formaron parte de la Logia, podemos decir que participaron mayoritariamente empleados, seguidos por comerciantes, profesionales e industriales, es decir, fundamentalmente sectores urbanos. En cambio, tal como se observa en el cuadro 4, prácticamente no habrían estado representados los intereses de los grandes latifundistas de la región, ya que la documentación registra la presencia de un solo estanciero.

\begin{tabular}{|c|c|} 
Cuadro 4. Perfil socio-ocupacional de los integrantes de la Logia \\
ACTIVIDAD & CANTIDAD \\
Empleado & 15 \\
Comerciante & 11 \\
Profesionales & 6 \\
Industrial & 4 \\
Militar & 2 \\
Estudiante de medicina & 1 \\
Marino & 1 \\
Estanciero & 1 \\
Propietario & 2 \\
Albañil & 1 \\
Carpintero & 2 \\
Agricultor & 1 \\
\hline
\end{tabular}

$21 \quad$ La presencia de estos actores sociales puede detectarse en las comisiones directivas o lista de socios de los primeros clubes deportivos, en la fundación de escuelas, en la actividad periodística local, como en muchas otras iniciativas del quehacer comunitario. La activa participación de españoles e italianos en la vida civil y política fue consolidándose en la medida en que se consolidaba la reciente capital territoriana. En el ámbito político local se destacó la presencia de estos grupos en los concejos municipales, en la formación de agrupaciones políticas y protagonizando conflictos significativos especialmente en los momentos previos y posteriores a los actos eleccionarios. Todo ello refleja la notable movilización de españoles e italianos en la red de poder local. Manara y Fernández, La problemática inmigratoria, 277.

22 Manara y Fernández, La problemática inmigratoria, 273. 
Elaboración propia con base en el expediente de la Logia "Obreros Luz del Neuquén”, AGLA, Buenos Aires, Argentina.

El predominio de empleados y comerciantes se corresponde claramente con la configuración de la economía local. A partir de 1904 la conversión de Neuquén en capital del Territorio brindó nuevas posibilidades a partir de la concentración de la actividad políticoadministrativa, dando lugar a un nuevo mercado laboral que permitió a muchos insertarse en la vida local ejerciendo funciones en la administración pública. De esta manera dentro de la categoría "empleados" se registran algunas ocupaciones, tales como: telegrafista, jefe de estación, jefe de Correos y Telégrafos, empleado del Juzgado Letrado, juez de Paz, subcolector de rentas y tesorero del banco. A su vez, paralelamente a la actividad pública, surgió una creciente demanda de bienes y servicios que fue un importante estímulo para la iniciativa privada, donde también ejercieron un rol de relevancia los inmigrantes españoles e italianos. De esta manera, afirman Manara y Fernández, la actividad terciaria se convirtió en la base predominante de la economía local. Según las autoras, la incidencia de la actividad comercial dio lugar al surgimiento de una incipiente burguesía neuquina ${ }^{23}$.

Tal como se desprende de los datos aportados por el cuadro 4, no se registran jornaleros y se observan muy pocos oficios manuales, esto podría ser un indicador de que la Logia tendía a vincularse fundamentalmente con las elites. El programa masónico, documento que analizamos en las próximas páginas, también brinda algunas pistas sobre la composición social de la institución y arroja luz sobre esta hipótesis. Uno de los puntos del programa señala: "La Masonería no necesita poderosos, pero tampoco admite en su seno personas que no tengan una ciencia, arte, oficio o renta con que poder atender las necesidades de su familia, y... un pequeño sobrante para hacer frente a los deberes que impone la institución y socorrer a los necesitados”.

En cuanto a la franja etaria de los integrantes de la Logia, la mayoría se ubicó entre los 20 y los 39 años, lo cual demuestra que los miembros eran hombres que se encontraban en plena etapa productiva y de inserción laboral. Junto a ello, otro aspecto que merece señalarse es que la mayoría de los integrantes residieron en la capital del territorio, dato representativo del carácter regional, urbano y circunscripto a espacios de acción locales de la masonería neuquina.

23 Manara y Fernández, La problemática inmigratoria, 275. 
Cuadro 5. Edad de los integrantes de la Logia

\begin{tabular}{c|c} 
EDAD & CANTIDAD DE \\
INTEGRANTES \\
20 a 29 & 18 \\
30 a 39 & 16 \\
40 a 49 & 7 \\
50 a 59 & 0 \\
60 a 69 & 1 \\
Sin datos & 2 \\
\hline Total & 44 \\
\hline
\end{tabular}

Elaboración propia con base en el expediente de la Logia “Obreros Luz del Neuquén”,

AGLA, Buenos Aires, Argentina.

\section{Ser masón en los territorios nacionales: algunas pautas a partir del programa masónico}

Para la incorporación a la Logia era requisito firmar una declaración con base en los lineamientos de un programa masónico, donde cada nuevo miembro se ofrecía bajo su "libre y espontánea voluntad y palabra de honor" como candidato a la Sociedad Masónica. La existencia de dicho programa es de común conocimiento en el campo de la historia de la masonería. En este sentido, ha sido analizado por historiadores del tema, como María de los Ángeles San Pedro Talabán, en su estudio sobre la masonería en Huelva, o por Ana Rodríguez en uno de sus trabajos sobre la masonería en el territorio pampeano ${ }^{24}$. En los tres casos se puede observar que los programas contienen los mismos lineamientos. El programa masónico que firmaban quienes ingresaban a la Logia “Obreros Luz del Neuquén”, señalaba:

La Masonería no se propone satisfacer ningún interés, ninguna mira egoísta: su objeto es altamente noble, su misión altamente humanitaria. Ella trabaja para el progreso moral, la caridad y la filantropía de todos los hombres de recta conciencia y buenas costumbres.

Pretender el ingreso a la Masonería por intereses privados o por objetos particulares, sería un absurdo, y efectuarlo sin encontrar en si toda la abnegación que la masonería demanda, es un engaño.

La Masonería tiene secretos fundados en la razón y la ciencia, que no pueden penetrase y juramentos que no pueden quebrantarse, pero ni unos ni otros se oponen a lo más a la religión, a las leyes y a la moral.

El aspirante que intente su incorporación por curiosidad, no prosigue su objeto, porque los misterios en que está la Masonería y que forman sus secretos, se van comunicando por grados, que se confieren después de muchas pruebas de fidelidad al que lo merece y nunca lo solicita.

24 María de los Ángeles San Pedro Talabán, “La Masonería en Huelva durante el siglo XX, 1900-1936”, Huelva en su historia 3 (1990): 505-602; Rodríguez, Los masones pampeanos de principios del siglo XX. 
El que se liga con un juramento y lo quebranta no infiere daño a la sociedad, el mal recae sobre el que no ha tenido constancia en cumplir un deber que voluntariamente se impuso.

La Masonería no exige a sus miembros la abjuración de los principios religiosos, ni osa penetrar en sus dogmas peculiares que pertenecen al fuero de la conciencia.

La Masonería no necesita poderosos, pero tampoco admite en su seno personas que no tengan una ciencia, arte, oficio o renta con que poder atender las necesidades de su familia, y sin menoscabo de estos deberes primordiales, un pequeño sobrante para hacer frente a los deberes que impone la institución y socorrer a los necesitados.

La Masonería no llenaría su grande objeto de fraternizar la especie humana, si admitiese discordia, pleitos y rinas entre sus miembros, toda diferencia debe arreglarse entre ellos mismos antes de apelar a personas extrañas, así es que si el candidato encontrase, después de admitirlo, algún individuo con quien no estuviese en buena armonía, está obligado a deponer su resentimiento, considerarlo como amigo y darle el abrazo fraternal.

Exige también la Masonería una parte del tiempo de sus miembros para la asistencia de sus reuniones o para el desempeño de alguna comisión, esto no puede negarse sin una causa legítima y poderosa.

Por último, el aspirante debe ejercitar la temperancia, ser industrioso y aplicado a su profesión, fiel a su jefe o maestro, practicar la virtud, partir su pan con el necesitado y no comer el de otro sin pagarlo, enseñar el verdadero camino al viajero extraviado, huir del juego, de la embriaguez, de la usura y de todos los vicios que condena la moral, y finalmente prestar a sus hermanos cuantos socorros, auxilio y protección le permitan las circunstancias, pero sobre todo trabajar con fe, constancia y entusiasmo por el triunfo de la verdad, sosteniendo una lucha incesante contra el fanatismo y la ignorancia en todas sus manifestaciones.

Acorde a las características del programa, las actas destacan en forma permanente la conducta ética y moral de los candidatos que solicitaban ingreso. Por ejemplo, el juego de azar era considerado como uno de los principales males que corrompía el carácter de los hombres de esas regiones. No obstante, también debemos destacar que en la práctica el programa no siempre fue respetado al pie de la letra. Fundamentalmente en lo que respecta a cuestiones como la "no admisión de discordias o pleitos entre sus miembros" o la idea misma de que "la masonería no necesita de poderosos". En este último caso debemos señalar que los vínculos con notables de la elite política, tanto del ámbito territoriano como nacional, significaron para la Logia un respaldo indudable. Un claro ejemplo lo constituye la incorporación de miembros importantes de la comunidad local, como, por ejemplo, Eduardo Talero, Secretario de la Gobernación e incorporado a la Logia en calidad de Venerable.

Por otra parte, ya en el último punto del documento, es interesante destacar la idea de una lucha incesante contra el fanatismo, ya que en el programa masónico que circuló en el territorio pampeano se hace referencia a la misma idea, siendo la palabra fanatismo reemplazada por la de oscurantismo, lo que dejaría entrever la existencia de ciertas tensiones entre la masonería local y el catolicismo en ambos territorios nacionales ${ }^{25}$. Más aún si tenemos en cuenta que en el programa

25 En el Territorio Pampeano el catolicismo fue considerado por la masonería como un enemigo. Rodríguez afirma que los masones de General Pico, por ejemplo, manifestaron ante las autoridades de la logia a nivel nacional que

REHMLAC+, ISSN 1659-4223, vol. 12, no. 2, diciembre 2019 / junio 2020 
masónico de la Logia de Huelva, mencionada anteriormente, es el único aspecto al cual no se hace referencia. Las actas de la Logia neuquina, por su parte, se refieren en forma asidua a la necesidad de eliminar el oscurantismo o a la idea misma de combate o lucha, nociones que arrojan luz sobre la posible existencia de un enemigo que los masones se proponían desterrar.

En uno de sus discursos, Eduardo Talero se refirió a las aspiraciones de la Logia y de manera expresa a la necesidad de estar unidos como forma de luchar contra el oscurantismo. Talero solicitó al Gran Arquitecto del Universo que:

...lo ilumine para realizar con acierto los trabajos del taller que, modesto, se acaba de instalar a las puertas del desierto confiando con el concurso de todos los hermanos engrandecerlo y aumentarlo con hombres de buena voluntad que aspiren a engrosar los fuertes eslabones de esa cadena universal ante la cual se estrellaran los desesperados esfuerzos del oscurantismo, viendo ya traslucir en lontananza, en la cima de la majestuosa Cordillera de los Andes la silueta de un grandioso templo masónico consagrado al progreso, a la libertad y a la fraternidad de todos los pueblos... ${ }^{26}$

El discurso de un masón en la tenida del 18 de febrero de 1906 refleja, una vez más, ciertas expresiones que nos permiten hipotetizar acerca de un vínculo conflictivo con el catolicismo, el cual es asociado con la mentira y el oscurantismo. En el acta se puede leer que el hermano tesorero Andres Imperiale,

...ha hecho un brillantísimo discurso sobre la causa liberal, exhortando a todos los hnos. a la verdadera unión fraternal, porque esa es la base para el triunfo cercano, de la luz, contra el error y la mentira....Los hnos. Romano Belli y Fernando Bazo Montero agradecieron por la concesión del 2 y grado sintiéndose dichosos de formar parte de las filas masónicas en las que combatirán con el mayor entusiasmo ${ }^{27}$.

La cita, además, es representativa del ideario masónico liberal y, en este sentido, permite entender por qué, como lo ha sugerido Gonzalez Bernaldo, la elite política liberal vio en este tipo de estrategias asociativas una herramienta valiosa para la generación de valores vinculados a la libertad y a la república ${ }^{28}$.

un profano y masón recién llegado había entablado vínculos con la Iglesia local. En palabras concretas se lamentaban que desde un primer momento dicho masón haya entablado vínculo con "nuestros enemigos los clericales". Cabe señalar que en la Pampa los vínculos entre la Iglesia católica y la masonería estuvieron atravesados por tensiones y conflictos. En dicho espacio, la presencia confesional católica fue hegemonizada por la Congregación Salesiana a quien el Arzobispo de Buenos Aires, Uladislao Castellano, otorgó la casi totalidad del Territorio. A través de la Misión de La Pampa (1896-1934), los salesianos se propusieron construir una sociedad pampeana católica. Este objetivo colisionó con los objetivos de quienes integraron las logias locales, quienes pretendían organizar el Territorio bajo los principios masónicos de la modernidad liberal. De manera concreta, los masones bregaron por la separación entre la Iglesia y el Estado y por frenar la creciente hegemonía del catolicismo en el Territorio. De este modo, las críticas al catolicismo, y en mayor medida a sus instituciones, fueron una constante. Las formas que adquirió la contestación fueron diversas y oscilaron entre la blasfemia, la denuncia y en algunos casos hasta la oposición concreta a medidas tomadas por las Iglesia. Ana María T. Rodríguez, "Los conflictos en torno a la construcción de una sociedad católica: voces anticlericales en el Territorio Nacional de La Pampa de principios del siglo XX (1896-1934), en Fronteras disputadas: religión, secularización y anticlericalismo en la Argentina (siglos XIX y XX), comps. Di Stefano y Zanca (Buenos Aires: Imago Mundi, 2016), 147-183.

26 Acta de la logia “Obreros Luz del Neuquén”, 1 de junio de 1905, AGLA, Buenos Aires, Argentina.

27 Acta de la Logia “Obreros Luz del Neuquén”, 18 de febrero de 1906, AGLA, Buenos Aires, Argentina.

28 Pilar Gonzalez Bernaldo, Civilidad y política, 281-283 
En otra oportunidad, el Ven. Maestro Domingo Mazzoni expresó en una de las tantas correspondencias al Secretario General Pedro Grande:

...Estamos trabajando con muchísimo empeño y con unión fraternal inmejorable y preparándonos sobre solido terreno para contrarrestar al enemigo negro que pretende avanzar sobre estas vírgenes regiones para echar su maléfica semilla ${ }^{29}$.

El 25 de mayo de 1907 los miembros de la Logia proyectaron la creación de la Biblioteca Popular "Rivadavia". En aquella oportunidad pronunciaron que dicha fundación no sólo se realizaba con el objetivo de dar más prestigio a la institución masónica, sino también como forma de combatir el oscurantismo, ofreciendo un salón de lectura a los habitantes de la Capital del Territorio. Este tipo de actividades también eran propiciadas por otras logias territorianas, como la ya mencionada Logia "Rivadavia", que además de involucrarse en la creación de una Biblioteca y de un centro cultural, participó en la promoción de instituciones de nivel medio y superior. Es decir, instituciones laicas que trajeron aparejado cierto malestar por parte de la Iglesia católica ${ }^{30}$. En el caso de Neuquén, Juan Di Bernardi, Ven. Maestro de la Logia, señaló que la construcción de la Biblioteca "Rivadavia" era una forma tangible de oponerse a los avances del oscurantismo que ya comenzaba a sentirse en ese Valle con la construcción de una capilla ${ }^{31}$. Efectivamente, la capilla "Nuestra Señora de los Dolores" se inauguró el 12 de septiembre de 1907 y fue la primera Iglesia católica de Neuquén².

Por último, cuando la Logia “Obreros Luz del Neuquén” fue declarada en sueño (suspensión de los trabajos) el masón Andrés Imperiale se dirigió al Gran Maestro con motivo de que le indicara cómo debía proceder para mantenerse activo y poder seguir propagando las ideas masónicas en favor de la libertad de pensamiento, con el fin de "combatir el oscurantismo que reina en estos lugares" ${ }^{33}$.

Ahora bien, más allá de las tensiones que dejan entrever las fuentes, es sabido que la relación entre la masonería y el catolicismo fue compleja. Por mencionar un ejemplo, algunas de las tenidas de la Logia “Obreros Luz del Neuquén” no sólo se iniciaban bajo los auspicios del Gran Oriente del Rito Azul sino también en nombre de San Juan Bautista. Esto indicaría que había miembros de la masonería que no tenían intención de renunciar a su fe católica. Estos aspectos nos advierten acerca de los matices y las porosidades en las que debemos reparar al momento de abordar estas cuestiones, pues resulta equívoco asociar al masón como opuesto al católico y viceversa.

\section{La inserción de los masones en el ámbito público local: redes,}

29 Acta de la Logia “Obreros Luz del Neuquén”, 11 de julio de 1906, AGLA, Buenos Aires, Argentina.

30 Bona, La Logia "Rivadavia", 10. Las disputas y conflictos entre la masonería y la Iglesia católica por el establecimiento de un determinado modelo educativo han sido analizadas, para el caso de Chile, por Ivonne Cortes. La autora demuestra cómo la masonería impulsó un proyecto educativo laico a partir de la fundación de la escuela "Blas Cuevas", y cómo la Iglesia católica se opuso a dicha iniciativa calificándola de "atea" e iniciando una ofensiva comunicacional en su contra. Ivonne Cortés, "Masonería y espacio público: El debate en torno a la "escuela atea" en Chile 1872", REHMLAC+ 10, no. 1 (mayo-noviembre 2018): 72-88, https://doi.org/10.15517/rehmlac.v10i1.32839

31 Acta de la Logia “Obreros Luz del Neuquén”, 31 de mayo de 1907, AGLA, Buenos Aires, Argentina.

32 Bandieri y Moroni, Prácticas asociativas, 101.

33 Acta de la Logia "Obreros Luz del Neuquén”, 12 de julio de 1908, AGLA, Buenos Aires, Argentina. 


\section{vínculos e influencias}

Como bien lo ha estudiado Bandieri, la influencia de la masonería en el ámbito territoriano, así como las redes de sociabilidad vinculadas a personas con poder de decisión en el Estado nacional pronto comenzaron a emerger ${ }^{34}$. En palabras de la autora, las incidencias de la Logia en la política y en el espacio público local se hicieron cada vez más evidentes, al ritmo de los cambios que simultáneamente se producían en el orden local y nacional.

A fines del año 1905 se puso en marcha el proceso para la formación del primer Concejo Municipal de Neuquén, donde participaron hombres de la Logia local, como por ejemplo, Domingo Mazzoni quien fuera Ven. Maestro. También se puede mencionar el caso del masón Tomás Martínez quien renunció a su cargo de Maestro de Ceremonias para ocupar el cargo de Juez de Paz en Plaza Huincó (Territorio Nacional de Neuquén), hechos que evidencian la inserción de los masones en el espacio público.

Por su parte, las reiteradas correspondencias al Secretario General, Pedro Grande, constituyen un claro ejemplo de las redes de influencias que comenzó a tejer la Logia. En algunas de esas cartas los masones pedían concretamente que se haga valer la influencia de la masonería en cuestiones vinculadas a la incorporación de ciertas personas en determinados cargos públicos. La injerencia de la institución masónica era tal que en una de las correspondencias manifestaron estar "alegres por el hecho de que su pedido al Supremo Consejo de la Orden se haya hecho efectivo con rapidez al ver llegar a este Valle al Inspector de Justicia Doctor Mendez, enviado por el Ministerio de Justicia, por los hechos que se producen en el Juzgado Letrado"35. Al respecto, es preciso mencionar que los miembros de la Logia mantuvieron una enconada disputa con el Juez Letrado del Territorio de Neuquén, Patricio Pardo. Las múltiples acusaciones en su contra, así como los cuestionamientos permanentes referidos al estado de la justicia en el Territorio, finalmente lograron hacerlo renunciar. El paso siguiente de los miembros de la Logia fue incidir en la elección de su remplazante. Situaciones similares tuvieron lugar en la Logia del Territorio Nacional de Santa Cruz, donde también se utilizaron los contactos de la masonería para influir en la designación del gobernador o de determinado candidato a Juez Letrado del territorio ${ }^{36}$.

El 11 abril de 1906 en una correspondencia a Pedro Grande, el Ven. Maestro acusó recibo de la plancha (escrito) que notificaba a los miembros de la Logia la probabilidad de que el territorio tenga al fin una justicia digna y buena, dado que "el Gran Oriente se ocupa con gran atención de ese asunto" ${ }^{37}$. En palabras del Ven. Maestro "mucho nos alegraría que viniese al Territorio para administrar justicia un elemento sano y bueno, pues todo el actual esta corrompido y es necesario depurarlo" 38 .

Luego de un altercado que Domingo Mazzoni mantuvo con el Juez Letrado Patricio Pardo se convocó a una tenida extraordinaria para tratar "exclusivamente de él” (en referencia

\footnotetext{
Bandieri y Moroni, Prácticas asociativas, 98.

Acta de la Logia “Obreros Luz del Neuquén”, 1 de abril de 1906, AGLA, Buenos Aires, Argentina.

Bona, La Logia "Rivadavia”, 6.

Acta de la Logia "Obreros Luz del Neuquén”, 11 de abril de 1906, AGLA, Buenos Aires, Argentina.

Acta de la Logia "Obreros Luz del Neuquén”, 11 de abril de 1906, AGLA, Buenos Aires, Argentina.
}

REHMLAC+, ISSN 1659-4223, vol. 12, no. 2, diciembre 2019 / junio 2020 
a Pardo) y expresaron que el voto unánime de los masones condensaba la aspiración de todo el territorio. El objetivo del encuentro fue solicitar que el Gran Oriente:

... nuevamente interponga su alta y prestigiosa influencia para la formación del juicio político al citado fuez [Pardol y la pronta suspensión del mismo y nombramiento de un sucesor nombrado en Buenos Aires, que evite a todo trance sea nombrado el actual Fiscal Dr. Foncueva, pues en ese caso tendríamos un ejemplar también malo ${ }^{39}$.

Al parecer la relación de los masones con el Fiscal de Neuquén tampoco transcurría en buenos términos, tal es así que, luego de la renuncia de Pardo, Rómulo Foncueva fue considerado como "el mal nuevo que nos amenaza y por dicha razón damos la voz de alerta para evitarlo con tiempo" ${ }^{\circ}$. En este sentido, solicitaban al Gran Oriente que velara e influyera para que se mande al territorio de Neuquén un Juez Letrado digno y verdadero, un honrado ciudadano, que no se deje imponer por las "aves negras" como hasta ahora ha sucedido aquí.

El problema con la justicia en el territorio neuquino, puntualmente bajo la gestión de Patricio Pardo, fue un tema que ocupó y preocupó a los masones y uno de los principales hechos que dejó notar tanto el poder como la injerencia política de los miembros de la $\operatorname{Logia}^{41}$. El 12 de junio de 1906 informaron que:

...Un hermano de alta influencia en las esferas oficiales va a tener una conferencia con el Ministro de fusticia respecto al grave asunto de la justicia letrada de este Territorio....pues este asunto se pone cada vez más grave aquí y el pueblo cada vez más exitado. Esto ya es intolerable y es una verdadera vergüenza para la nación ${ }^{42}$.

Finalmente, el Juez Letrado Patricio Pardo fue remplazado por un masón, Miguel Duarte. El hecho fue enunciado gratamente:

Nos es grato comunicar que hemos visto con placer llegar a este Territorio al nuevo fuez Letrado Miguel Duarte y más alegría experimentamos al saber de que también es hno., grado 3, perteneciente al Rito Confederado ${ }^{43}$.

Duarte procedía del Territorio Nacional de La Pampa, un dato interesante que arroja luz no sólo sobre la movilidad de los integrantes de las logias de territorios limítrofes, sino también sobre la trama de relaciones e influencias sociales y políticas tejidas por la masonería.

39 Acta de la Logia "Obreros Luz del Neuquén”, 1906, AGLA, Buenos Aires, Argentina.

40 Acta de la Logia “Obreros Luz del Neuquén”, 12 de junio de 1906, AGLA, Buenos Aires, Argentina.

41 Según afirman Favaro y Morinelli, el Juez Letrado del Territorio era un funcionario que se manejaba con un amplio margen de libertad e independencia de las autoridades territorianas, problema que se veía agravado cuando el cargo recaía en personas poco idóneas. Por este motivo fueron frecuentes los conflictos que el Gobernador del Territorio mantuvo con este tipo de funcionario público. Orietta Favaro y Marta Morinelli, "La política y lo político en Neuquén: la política territoriana en el marco del desenvolvimiento económico y social de Neuquén (1884-1955)", en Historia de Neuquén, 289-314.

42 Acta de la Logia "Obreros Luz del Neuquén”, 12 de junio de 1906, AGLA, Buenos Aires, Argentina.

43 Acta de la Logia “Obreros Luz del Neuquén”, 2 de octubre de 1906, AGLA, Buenos Aires, Argentina. 
A poco tiempo de ser designado, Miguel Duarte visitó la Logia, fortaleciendo así los lazos con la masonería local. En carta al Secretario General se informó que en la tenida pasada:

...tuvieron el placer de recibir la distinguida presencia del hno. Miguel Duarte. Fue recibido con toda distinción y usó la palabra con elocuencia. Expresó sus sentimientos de gratitud por los elogios que hacia su persona hacía el Gran Oriente en una plancha que fue remitida a la Gran Logia...Recordó con cariño a la logia Lautaro del Rito Confederado del Valle de Río Cuarto que le concedió el honor de quitarle la venda de los ojos para hacerle ver la verdadera luz ${ }^{44}$.

Tal como lo señala Bandieri, para mediados de 1906 la Logia parecía estar en su apogeo, los masones no sólo habían logrado remplazar a un Juez Letrado sino también influir en la designación del nuevo Gobernador del Territorio ante la renuncia de Carlos Bouquet Roldán, quien se trasladó a Buenos Aires para “ocupar un alto puesto en la Administración Nacional” Las simpatías de la masonería con Bouquet Roldan fueron evidenciadas en una suma de elogios. De manera concreta, su administración fue concebida como "la más fecunda en grandes obras e iniciativas que haya tenido el territorio desde su organización administrativa, su espíritu liberal y de incasable luchador por el bienestar del pueblo ha llegado a poner al territorio del Neuquén entre uno de los primeros de la nación” ${ }^{* 6}$. En esta oportunidad los miembros de la Logia apelaron a sus influencias para poner en lugar del ex gobernador a Eduardo Elordi, miembro de la Logia y Secretario de Bouquét Roldán. Así lo expresaron:

...En estos momentos de ansiedad el pueblo entero del territorio se adhiere con sus miles de firmas al Exmo. Sr Presidente de la Republica [Figueroa Alcorta] expresando los deseos que laten en los corazones de los buenos ciudadanos y pidiendo que apenas sea aceptada la renuncia de Bouquet Roldán sea nombrado el dignísimo sucesor de sus grandes obras e iniciativas, su actual secretario, Sr. Eduardo Elordi. Esta es la aspiración legítima y unánime del pueblo entero del Territorio que ven en el sr. Elordi un dignísimo continuador de las patrióticas iniciativas de Carlos Bouquet Roldan y un funcionario recto, honrado y liberal que ya tiene bien ganada fama en su carrera política de la cual no hace muchos días terminó su periodo de Diputado Nacional por Tucumán+7.

Junto con la renuncia de Patricio Pardo, que los masones presentaron como una aspiración de todo el territorio, la cita precedente también aporta evidencia a la hipótesis de Bonaudo, acerca de cómo las logias decantaron en instituciones que se proyectaron políticamente, creando una gama de vínculos y solidaridades que impactaron en el interior de las tramas jurisdiccionales y operaron como instancias de mediación entre los individuos y el Estado, incidiendo en la conformación de las identidades ciudadanas ${ }^{48}$.

La masonería local también influyó en la designación de un miembro de la Logia, Fernando Bazo Montero, como Gerente de la Sucursal del Banco de la Nación, y del masón Mateo Echegaray como Jefe de la Oficina de Correos. En este último caso, hay constancia de

\footnotetext{
44 Acta de la Logia “Obreros Luz del Neuquén”, 17 de octubre de 1906, AGLA, Buenos Aires, Argentina.

45 Bandieri y Moroni, Prácticas asociativas, 102.

46 Acta de la Logia "Obreros Luz del Neuquén”, 10 de mayo de 1906, AGLA, Buenos Aires, Argentina.

47 Acta de la Logia “Obreros Luz del Neuquén”, 10 de mayo de 1906, AGLA, Buenos Aires, Argentina.

48 Bonaudo, Liberales, masones, 404.
} 
la correspondencia a Pedro Grande agradeciéndole por las diligencias realizadas referentes al pedido hecho por los masones respecto al hermano Mateo Echegaray. Por otra parte, el 3 de octubre de 1907 los miembros de la Logia se dirigieron al Secretario General, Antonio Zuñiga, con motivo de indicarle que el hermano Moris Giménez, caracterizado como un buen liberal, tenía necesidad absoluta de que se influya a su favor en la oficina de tierras y colonias y en la Dirección General de Correos y Telégrafos por asuntos que "el querido hermano os explicará”. La correspondencia finalizaba con un agradecimiento por ayudar a dicho hermano del modo que se considere más eficiente ${ }^{49}$.

Ahora bien, pese al éxito de la inserción de la Logia en la sociedad local y a su influencia política, la movilidad de sus integrantes, como señalamos en páginas anteriores, fue motivo de preocupación por parte de las autoridades. Los traslados por motivos laborales, las renuncias, pases o radiaciones fueron aspectos que comenzaron a obstaculizar los trabajos de la institución por falta de número suficiente para sesionar. Según consta en las actas esta situación motivó que, en julio de 1907, por unanimidad de votos, la Logia fuera declarada en sueño por tiempo indeterminado. De esta manera, "Obreros Luz del Neuquén" constituye un ejemplo más del carácter efímero que tuvieron las logias en los territorios nacionales estudiados hasta el momento ${ }^{50}$.

Sobre la interrupción de los trabajos, los masones manifestaron:

...en las circunstancias actuales del taller no es posible mantenerlo regularmente, máxime si se tiene en cuenta que varios hnos. que no asisten a los trabajos se encuentran separados o divididos por discordias o intrigas que no ha sido posible solucionar de un modo satisfactorios.

Tal como deja notar la cita precedente, las divisiones, tensiones y disputas al interior de la Logia pronto comenzaron a emerger. Tanto es así que los enfrentamientos entre sus miembros parecen haber sido virulentos cuando no irremediables, al punto de motivar la creación de otra Logia, en este caso, auspiciada por el Rito Escocés.

\section{Logia "La Verdad"}

\section{Creación}

Los inicios del Triángulo "La Verdad" se remontan al año 1906 cuando un grupo de cuatro masones salidos de la logia Obreros Luz del Neuquén comenzaron a pensar en su formación. Según consta en la documentación, en la tenida del 14 de junio de 1906 José Edelman, Benjamín Pinna, Aditardo Ozzan y Ferruccio Verzegnassi, los tres residentes en el Valle de Neuquén y ex integrantes de la logia Obreros Luz del Neuquén, declararon la necesidad de fundar un Triángulo perfecto y regular bajo los auspicios o protección del Rito

49 Acta de la Logia “Obreros Luz del Neuquén”, 3 de octubre de 1907, AGLA, Buenos Aires, Argentina.

50 En el territorio pampeano ninguna de las logias existentes funcionó más de cinco años: "Libertad" (General

Acha, 1907-1910), "Estrella de La Pampa” (Santa Rosa, 1907-1912), "Luz de La Pampa” (General Pico, 1909-1914),

"Triángulo Luz de La Pampa" (Catriló, 1923-1924). Rodríguez, Masones en el interior, 182.

51 Acta de la Logia “Obreros Luz del Neuquén”, o1 julio 1907, AGLA, Buenos Aires, Argentina. 
Escocés Antiguo y Aceptado. Dicho anhelo finalmente se concretó y el Triángulo se formó con el nombre distintivo de "La Verdad", erigiéndose bajo los auspicios de dicho rito. Sobre lo sucedido en esa primera tenida puede leerse:

Se reúnen los obreros masones en número de 4, deseando levantar un nuevo templo y establecerse en triángulo perfecto y regular de los 3 primeros grados simbólicos del Rito Escoses Antiguo y Aceptado. Se han reunido entre la escuadra y el compás bajo la dirección del Mallete del muy querido hno. Fosé Edelman $18^{\circ}$ que tomando asiento en el Oriente ha nombrado para acompañarle en los trabajos al hno. Benjamin Pinna encargado de la vigilancia de los obreros en el Sur y Norte, Ferruccio Verzeganasi, $3^{\circ}$ desempeñó las funciones de orador, Ozzan recibió el Curil para trazar el bosquejo de los trabajos y Benjamin P. las funciones de Tesorero y Guarda Sellos ${ }^{52}$.

En esta misma oportunidad se solicitó al Gran Maestro de la Orden la necesidad de contar con una carta constitutiva que ofreciera al Triángulo la respectiva formalidad. Señalaron al respecto:

Animados del deseo de trabajar regularmente por el progreso de la masonería y el bien general de la humanidad os rogamos que nos agreguéis al centro común de los masones de la R. Argentina otorgándonos la Carta Constitutiva que regularice el triángulo que hemos formado provisoriamente bajo el titulo distintivo de La Verdad, en el Rito Escocés Antiguo y Aceptadoss.

Finalmente, el Poder Ejecutivo de la Orden declaró incorporar a la obediencia del Consejo y Gran Oriente la constitución y la regularidad formal del Triángulo "La Verdad" en el Valle del Neuquén.

\section{Cuadro . N\%: Miembros fundadores de la Logia "La Verdad"}

\begin{tabular}{|c|c|c|c|c|c|c|c|}
\hline NOMBRE & $\begin{array}{l}\text { FECHA DE } \\
\text { NACIMIENTO }\end{array}$ & $\begin{array}{l}\text { NACIO- } \\
\text { NALIDAD }\end{array}$ & GRADO & $\begin{array}{l}\text { OFICIO/ } \\
\text { PROFESIÓN }\end{array}$ & DOMICILIO & $\begin{array}{l}\text { FECHA DE } \\
\text { ADMISIÓN EN } \\
\text { LA ORDEN }\end{array}$ & $\begin{array}{l}\text { LOGIA A LA QUE } \\
\text { PERTENECIÓ }\end{array}$ \\
\hline José Edelman & 14 abril de 1873 & Rumana & 18 & Comerciante & Neuquén & $\begin{array}{l}15 \text { diciembre de } \\
1990\end{array}$ & $\begin{array}{l}\text { "Pytagoras" } \\
\text { (Buenos Aires) }\end{array}$ \\
\hline Benjamín Pinna & $\begin{array}{l}31 \text { mayo de } \\
1880\end{array}$ & Italiana & 3 & Comerciante & Neuquén & 15 junio 1905 & $\begin{array}{l}\text { "Obreros Luz del } \\
\text { Neuquén } N^{\circ} 95 "\end{array}$ \\
\hline Aditardo Ozzan & 1 abril de 1884 & Argentina & 3 & Profesor & Neuquén & 15 junio de 1905 & $\begin{array}{l}\text { "Obreros Luz del } \\
\text { Neuquén } \mathrm{N}^{\circ} 95 \text { " }\end{array}$ \\
\hline $\begin{array}{l}\text { Ferruccio Verze- } \\
\text { gnassi }\end{array}$ & $\begin{array}{l}12 \text { octubre de } \\
1875\end{array}$ & Austriaca & 3 & Farmacéutico & Neuquén & 20 marzo de 1903 & $\begin{array}{l}\text { "Italia" } \\
\text { (Buenos Aires) }\end{array}$ \\
\hline
\end{tabular}

Elaboración propia en base al expediente de la Logia “Obreros Luz del Neuquén”, AGLA, Buenos Aires, Argentina.

En la segunda tenida que tuvo lugar el 18 de junio de 1906 los masones procedieron a convocar a elecciones con motivo de designar a las autoridades del nuevo Triángulo. Dicha votación fue secreta y dio los siguientes resultados provisionales: Ven. Maestro interino,

52 Acta de la Logia "La Verdad", 14 de junio de 1906, AGLA, Buenos Aires, Argentina.

53 Acta de la Logia "La Verdad", 11 de junio de 1906, AGLA, Buenos Aires, Argentina. 
Ferruccio Verzegnassi; Secretario interino, Aditardo Ozzán y Tesorero Interino, Benjamin Pinna. Posteriormente, José Edelman postuló que, tratándose de un Triángulo, la incipiente institución debía contar con un presidente, un tesorero y un secretario para el ejercicio del año en curso, es decir, 1906. De esta manera, proclamó para ocupar los respectivos cargos a los siguientes masones: Ferruccio Verzegnassi (presidente), Aditardo Ozzan (secretario) y Benjanmín Pinna (tesorero).

En cuanto al sostenimiento de la institución, consta en el expediente la fijación de una cuota mensual y de un impuesto extraordinario para poder proveer de fondos al Triángulo. Por su parte, el 27 de octubre de 1906, según consta en correspondencia al Superior Consejo de la Orden, sus miembros manifestaron la necesidad de elevar el Triángulo a Logia Regular y Perfecta en virtud de la calidad moral, intelectual y material que ofrecía el taller. En este contexto solicitaron la dispensa de tiempo para la iniciación y aumento de grado hasta el 3 en vista de poder elevar el taller a Logia.

Una vez fundado el Triángulo comenzó el proceso de iniciación de profanos. Entre ellos se destacan Ernesto Gari, 27 años, natural de Buenos Aires, soltero, comerciante, propietario, estanciero, librepensador, de informes favorables y posición social importante; Jorge González Larrosa, soltero, 26 años, domiciliado en Colon, Lucinda (Territorio Nacional de Río Negro), estanciero y librepensador; Juan González Larrosa, 21 años, domiciliado en Colonia Lucinda, estanciero, librepensador, nacido en San Juan. Datos que aportan detalles sobre el perfil etario, socio ocupacional e ideológico de los miembros aceptados.

\section{Disputas, tensiones y divisiones en la masonería local}

En el ámbito nacional, en 1873 la masonería se vio sacudida por una profunda crisis interna que culminó con la formación de tres agrupaciones rivales. Por su parte, en 1898, tuvo lugar una nueva ruptura a partir de la cual un grupo de masones fundó la Gran Logia Nacional Argentina que reclamó para sí la genuina representación del llamado Rito Escocés Antiguo, que había sido aceptado en Argentina. En 1902, un grupo de logias dependientes del Gran Oriente y Supremo Consejo para la República Argentina (principal centro donde confluían más de un centenar de logias) decidió separase y fundar el Rito Azul, en disidencia con el Rito Escocés Antiguo ${ }^{54}$. Este hecho inauguró un periodo donde la disidencia fue frecuente y el choque de ideas, agravado por el enfrentamiento personal, terminó por alentar graves movimientos secesionistas ${ }^{55}$. La división que afectó a la masonería a nivel nacional se extendió a los territorios nacionales, como se puede observar en el caso de Neuquén.

A partir de la lectura de los expedientes de las dos logias estudiadas, podemos inferir que la constitución de la Logia "La Verdad" habría estado motivada por la crisis y fragmentación que en torno al año 1906 comenzó a atravesar la Logia “Obreros Luz del Neuquén”. Como ya lo sugerimos anteriormente, las disidencias al interior de dicha Logia habrían motivado

54 El Rito Azul rechazaba el mantenimiento de los altos grados escocistas $-4^{\circ}$ a al $33^{\circ}$ - de la tradicional logia argentina, y postuló organizarse sobre la base de los tres primeros grados o grados azules $-1{ }^{\circ}$ Aprendíz, $2^{\circ}$ Compañero, $3^{\circ}$ Maestro-.

55 Mayo, La masonería en crisis, 4-6. 
la constitución de un nuevo Triángulo. Según Bandieri, la escisión de la masonería a nivel local habría acompañado la fragmentación interna de la masonería argentina, proceso que fue minando paulatinamente la dirección e influencia que aquella detentó hasta fines del siglo XIX. Asimismo, señala la autora, conviene pensar hasta qué punto los enfrentamientos políticos a nivel local también podrían ayudar a explicar tal división ${ }^{56}$.

El o6 de mayo de 1906 el masón Ferruccio Verzegnassi, miembro fundador de la Logia "Obreros Luz del Neuquén” y "La Verdad", en una correspondencia al Secretario del Gran Consejo de las Logias Masónicas del Antiguo y Aceptado Rito Escocés solicitó poder afiliarse a dicho rito, donde había sido iniciado, en virtud de las tensiones que tenían lugar en el interior de la Logia “Obreros Luz del Neuquén”. En sus palabras:

...cuando las ambiciones, deseos de inmerecida distinción, cuando el carácter inapto para ser masones de algunos hermanos de la logia Obreros Luz del Neuquén, cuando las bajas pasiones presionan más que el dominio de sí mismo entonces la hermandad quebranta y junto a otros pocos hermanos he tenido que luchar por la existencia de la logia Obreros Luz del Neuquén que algunos querían quebrantar. La logia se dividió así en dos partes enemigas, en dos facciones. Fui condenado infiel pese a conocer mis méritos como defensor de los derechos y de la existencia de la logia Obreros Luz del Neuquén, conociéndome por mi espíritu liberal $y$ de progreso, sabiendo algunos que he luchado desde la infancia en las filas del partido liberal en mi Patria (Austria) en donde luche en pos de la libertad, nacionalidad e ideales. Pero me dejaron sin asiento no invitándome más a reuniones. Fue por este motivo que yo escribiera una carta al Ven. de la logia Obreros Luz del Neuquén pidiendo por motivos personales mi pase ${ }^{57}$.

Las actas de ambas logias hacen referencia asidua a las tensiones existentes. En carta al Secretario General Pedro Grande, el Ven. Maestro de la Logia “Obreros Luz del Neuquén”, Juan Di Bernardi, manifestó lo siguiente sobre la conformación del Triángulo "La Verdad” y sus fundadores:

...en este valle se ha conformado un triángulo compuesto por los señores Benjamin Pinna, Ferruccio Verzegnassi y fosé Edelman que trabajan según manifiestan bajo los auspicios del Rito Escoces. En consecuencia, este taller desearía conocer si efectivamente es reconocido dicho triángulo por el Rito Escoces o si en su defecto es irregular a fin de no recibirlos en nuestro Taller en el caso que se presenten como visitantes.

Edelman está afiliado o a pertenecido a la Logia Pitágoras del Valle de BsAs, pero Pinna fue radiado como usted recordará por faltas graves de nuestro rito, y Verzegnassi se le otorgó el pase con fecha febrero de 1906 y nos extrañaría mucho que estos dos últimos hayan sido admitidos en el rito escoses ${ }^{58}$.

\footnotetext{
56 Bandieri, Sociedad civil, 65.

57 Acta de la Logia "La Verdad", o6 de mayo de 1906. AGLA, Buenos Aires, Argentina.

58 Acta de la Logia “Obreros Luz del Neuquén”, 5 noviembre 1906, AGLA, Buenos Aires, Argentina.
}

REHMLAC+, ISSN 1659-4223, vol. 12, no. 2, diciembre 2019 / junio 2020 131pg 
En otra correspondencia a Pedro Grande un grupo de masones integrantes de la Logia “Obreros Luz del Neuquén” (Eduardo Talero, Domingo Mazzoni, Emilio Rodríguez Iturbide, Luis de Lope y Andrés Imperiale) informaron al Secretario General que habían decidido radiar (expulsar) de la Logia a algunos hermanos, entre ellos, Benjamín Pinna y Aditardo Ozzan, (quienes posteriormente fundaron el Triángulo "La Verdad"). Acto seguido, los masones procedieron a cambiar de domicilio la Logia a fin de "cortar de una vez por todas el escándalo producido por el mal elemento que acaba de ser radiado y evitar que profanamente llegara a ser motivo de burlas" ${ }_{59}$. Agregaron, "nos posesionamos de la logia y solo pudimos encontrar los muebles, pues los libros de actas, copiadores, archivos y el sello, han desaparecido llevados por los hermanos que acaban de ser radiados. La carta constitutiva obra en nuestro poder, pues en previsión de lo que iba a suceder nos apoderamos de ella" ${ }^{60}$. Finalmente, señalaron:

...Privados de este elemento pernicioso que obstaculizaba la buena marcha de la logia produciendo la discordia en el seno de la misma...una nueva era de paz y progreso se inicia para la Logia que ahora recién podrá cumplir dignamente con su noble deber manteniendo a la altura que se merece la enseña que nos cobija del Rito Azul ${ }^{61}$.

Por su parte, el acta de la Logia "La Verdad" deja constancia de la separación de Benjamín Pinna y Aditardo Ozzan del grupo inicial de la Logia “Obreros Luz del Neuquén”. El 14 de octubre de 1906, en correspondencia al Gran Maestro de la Orden, Benjamín Pinna declaró "haber sido auspiciado al grado de Maestro el 2 de septiembre de 1905 en la logia Obreros Luz del Neuquén del Rito Azul y no haber sido entregado el diploma por causas de las desavenencias surgidas en torno a aquella logia. Habiéndose separado de aquella logia no retiró ni quiso retirar el diploma” ${ }^{62}$. El objetivo de la correspondencia consistió en solicitar al Supremo Consejo de la Orden que le sea cargado su diploma de masón regular, condición necesaria para efectuar el pase de una Logia a otra. En el mismo sentido, se efectuó el pedido de Aditardo Ozzan quien también declaró haber sido auspiciado al grado de Maestro y no contar con la posesión del diploma por la misma causa que Pinna. Por su parte, José Edelman, otro de los fundadores del Triángulo, declaró habérsele quemado su diploma de Maestro y otros documentos masónicos en ocasión de un incendio producido en su casa. Quien sí obtuvo su diploma fue Verzegnassi. Dicho documento, deja constancia que el día 10 de junio de 1905 fue recibido e iniciado en el grado de Maestro Masón. De esta manera, el 14 de octubre de 1906 se dirigió al Gran Maestro de la Orden con motivo de enviar el diploma otorgado, darlo de baja, y solicitar se le otorgue otro diploma de masón regular por el Superior Consejo del Rito Escosés.

Las tensiones entre los masones de ambos ritos claramente fueron transmitidas al Supremo Consejo de Gobierno en diferentes correspondencias. En una de ellas, enviada el 23 de septiembre de 1906, plantearon que en la tenida del 22 de septiembre decidieron pedir a ese órgano de gobierno algunos consejos y resoluciones sobre algunas cuestiones.

\footnotetext{
59 Acta de la Logia “Obreros Luz del Neuquén”, 22 de octubre de 1905, AGLA, Buenos Aires, Argentina.

6o Acta de la Logia "La Verdad", 22 de noviembre de 1905, AGLA, Buenos Aires, Argentina

61 Acta de la Logia "La Verdad", 22 de noviembre de 1905, AGLA, Buenos Aires, Argentina.

62 Acta de la Logia "La Verdad", 14 de octubre de 1906, AGLA, Buenos Aires, Argentina.
} 
La primera de ellas consistía de manera concreta en un interrogante: ¿cómo debían comportarse con los maestros irregulares y demás afiliados del Rito Azul independiente que pertenecían a la Logia Obreros Luz del Neuquén? A lo cual señalaron que, en su opinión, debían ser considerados irregulares, salvo "aquellos más dignos de estimación por su conducta y calidad morales y que inconscientemente fueron atraídos por falsas luces". Además, prosiguieron, ser miembro del otro Rito no era comprobante suficiente para tener derecho a afiliarse al Gran Oriente para la República Argentina, por el contrario, antes se debía pasar por todos los trámites y averiguaciones necesarias como si se tratase de un profano. La aclaración tenía lugar dadas las irregularidades morales existentes en esa asociación. Por último, indicaron que la calumnia y la discordia se habían apoderado de la Logia “Obreros Luz del Neuquén”, que decía haberse formado bajo los auspicios de la paz y la hermandad.

La segunda cuestión se refería concretamente a la decisión de no admitir como candidatos a hombres que por más buenas cualidades morales que posean, o por más amigo, camarada u hombre de principios sanos y liberales que sea, no tenga la firmeza de carácter suficiente como para no dejarse dominar por la mala y destructora posesión del juego de azar. Siendo la calumnia y la pasión por el juego los dos males que, según los masones, más atacaban el carácter de los hombres en esas regiones se creía justo combatirlos con la máxima severidad y solicitaban consejos al respecto.

En carta al Supremo Consejo de Gobierno, Ferruccio Verzegnassi enfatizó en la crisis que atravesada la masonería local al señalar de manera concreta el carácter despótico del Rito Azul, como así también su irregularidad y el hecho de haber caído en manos de hombres que pusieron la causa masónica a servicio y defensa de sus propios intereses. De esta manera, los miembros de la Logia "Obreros Luz del Neuquén” eran considerados por los masones de la Logia "La Verdad" como uno de los enemigos con quien luchar. En la misma correspondencia, Verzegnassi solicitó al Supremo Consejo información de Horacio Pérez, nativo de Navarro, Buenos Aires, escribano público en la capital de Neuquén y que había pedido ingresar a la masonería. Según Verzegnassi, antes de proceder a su ingreso era necesario conocer sus antecedentes "por ser de común opinión que Pérez era de filiación clerical-político" ${ }_{63}$. Por los mismos motivos, Verzegnassi manifiestó el interés de todos los hermanos por conocer la filiación política del ya mencionado Dr. Foncueva, Fiscal de Neuquén. Estas acciones dejan entrever, una vez más, las redes e influencias que tejía la masonería local, en este caso, las que comenzaban a tejer los miembros de la nueva Logia.

\section{Conclusiones}

En este artículo estudiamos la creación y funcionamiento de dos logias, "Obreros Luz del Neuquén” y "La Verdad”, que funcionaron en el Territorio Nacional de Neuquén en los primeros años del siglo XX. La investigación constituye un aporte a los estudios sobre la masonería en Argentina y resignifica la sociedad territorial como objeto de estudio, al destacar el rol que la masonería y los masones, hasta hace pocos años ignorados, tuvieron

63 Acta de la Logia "La Verdad", 3 de noviembre de 1906, AGLA, Buenos Aires, Argentina. 
en la configuración de los territorios nacionales. Como pudimos ver, las logias jugaron un papel importante dentro de la sociedad civil en el contexto de formación de dichos espacios. Como señala Bonaudo, el accionar de las logias se proyectó más allá de las instituciones y sus adherentes, produciendo así diferentes intercambios en el marco de un público mayor ${ }^{64}$. De esta manera, el abordaje de la masonería en el territorio nacional de Neuquén constituye un tema de estudio relevante que implica tener en cuenta múltiples factores, entre ellos, el involucramiento de los masones con los sectores de poder (local, territoriano y nacional), los intereses en juego, las acciones realizadas para incidir en el plano político, así como las tensiones y divisiones al interior de la masonería.

Sin duda, en Neuquén la masonería constituyó, al igual que en otras logias de territorios nacionales, como La Pampa o Santa Cruz, una forma de integración de las elites a una sociedad en construcción, donde todo estaba por hacerse. Compuesta mayormente por sectores urbanos, la masonería mantuvo estrechas relaciones con los notables del territorio, fundamentalmente con la elite política, supo tejer un entramado de vínculos e influencias y fue protagonista de conflictos y tensiones por los espacios de poder. A partir de estos vínculos y de los lazos que mantuvo con las autoridades masónicas a nivel nacional la masonería neuquina se involucró en los problemas del territorio. En el año 1906 la documentación de la Logia “Obreros Luz del Neuquén” permite conocer una de las principales preocupaciones de sus miembros. De manera concreta, los masones se propusieron lograr la destitución del Juez Letrado Patricio Pardo, a quien lograron remplazar por Miguel Duarte, un masón procedente del Territorio Nacional de La Pampa. Dicho conflicto permite advertir cómo en un marco de debilidad de las identidades partidarias, la masonería permitió tratar, poner en debate y accionar ante este tipo de situaciones que hacían a la dinámica política del territorio ${ }^{65}$.

Como pudimos observar, el acceso de la masonería a sus redes de poder para incidir en decisiones que involucraban a sus miembros y al territorio fue recurrente. Siguiendo la hipótesis de Bona, se podría decir que los masones funcionaron como grupo de presión, en la medida en que actuaron a través de las autoridades de la Gran Logia Argentina sobre el gobierno territoriano para imponer sus aspiraciones o reivindicaciones ${ }^{66}$. Este accionar de la masonería visible en el Territorio Nacional de Neuquén permite comprobar, como sostiene Bandieri, la existencia de importantes redes de relaciones que hacían de la pertenencia a la orden una garantía de éxito para revisar determinadas medidas del poder central y favorecer así intenciones políticas de sus miembros, ya sea para elegir un funcionario gubernamental o para imponer un candidato en un cargo directivo en organismos públicos dependientes del orden nacional. Esta facultad parece haber estado presente sobre principios de siglo cuando todavía las logias ocupaban lugares de privilegio en el poder nacional. Esta idea, además, contribuye a romper con cierta historiografía que plantea el aislamiento y la falta de articulación nacional de las elites patagónicas producto de la lejanía de los territorios nacionales respecto del poder central ${ }^{67}$.

\footnotetext{
64 Bonaudo, Liberales, masones, 404.

65 Es relevante señalar que, en consonancia con lo que ocurrió a nivel nacional, a mediados del siglo XX el surgimiento de los partidos políticos orgánicos y de otras formas asociativas, disminuyeron paulatinamente la importancia de las logias y su rol de mediadoras entre la sociedad civil y el poder político.

66 Bona, La Logia “Rivadavia”, 11.

67 Bandieri, La masonería en la Patagonia, 36.
} 
La investigación también contribuyó a reflexionar sobre la incidencia de la masonería en la construcción de la secularización territoriana. Si bien la documentación no nos permitió profundizar en este aspecto, a partir de algunos datos aportados fundamentalmente por las actas de la Logia “Obreros Luz del Neuquén”, pudimos hipotetizar acerca de una relación conflictiva o al menos tensa con el catolicismo. La creación de una institución laica como la Biblioteca "Rivadavia" o la referencia frecuente a la idea de un combate contra el oscurantismo, constituyen algunos ejemplos. En suma, las logias expresaron los valores liberales de los masones y fueron instituciones comprometidas de diferente manera con la construcción de un Estado laico. En este contexto, disputaron con la Iglesia católica el espacio público local. De ahí que estudiar la masonería también implique tener en cuenta los vínculos que estas instituciones y sus actores mantuvieron con el catolicismo.

Por último, las vinculaciones de los masones con otras instituciones locales, como los concejos deliberantes, el juzgado de paz o las bibliotecas populares, nos permiten pensar en las logias como ámbitos de sociabilidad que, más allá de sus funciones específicas, contribuyeron a crear vínculos y solidaridades en una sociedad móvil, en la cual las identidades, las redes de poder y de sociabilidad también estaban en construcción. Parafraseando a Aghulon, en todas las épocas nunca es completa la separación entre el fin oficial de una asociación y la difusa función de sociabilidad ${ }^{68}$. Destacar estos aspectos no sólo permite rescatar las prácticas y experiencias de los masones de principios de siglo sino también pensarlos como personas con una vida política y social intensa y activa. Esta perspectiva contribuye a desmitificar la idea de los masones como personas ocultas o replegadas sobre su propia institución.

\section{Bibliografía}

Agulhon, Maurice. El círculo burgués. La sociabilidad en Francia, 1810-1848. Buenos Aires: Siglo XXI, 2009.

Bandieri, Susana. "Ampliando las fronteras. La ocupación de la Patagonia”. En El progreso, la modernización y sus límites (1880-1916). Dirigido por Mirta Zaida Lobato. Buenos Aires: Sudamericana, 2000.

Bandieri, Susana. "Sociedad civil y redes de poder social en los territorios Nacionales del Sur: Neuquén, Patagonia argentina, 1880-1907”. Boletín Americanista LVII, no. 57 (2007):53-68

Bandieri, Susana. "La masonería en la Patagonia. Modernidad liberal y asociacionismo masón en Neuquén (1884-1907)”. Estudios Sociales 38 (primer semestre 2010):9-38. DOI: https://doi.org/10.14409/es.v38i1.2652

Bandieri, Susana y Moroni, Marisa. "Prácticas asociativas seculares, poder y política: masones en Neuquén y espiritistas en La Pampa en la primera mitad del siglo XX”. En Estudios

68 Maurice Agulhon, El círculo burgués. La sociabilidad en Francia, 1810-1848 (Buenos Aires: Siglo XXI, 2009). 
de Historia Religiosa argentina (siglos XIX y XX). Editado por Ana María Teresa Rodríguez. Rosario: Prohistoria ediciones, 2013.

Bona, Aixa. "La Logia Rivadavia en el Territorio de Santa Cruz. 1920-1944". Ponencia presentada en las sas fornadas de Historia de la Patagonia, San Carlos de Bariloche, 6-8 de noviembre 2008.

http://www.hechohistorico.com.ar/Trabajos/Jornadas\%2ode\%2oBariloche\%20-\%202008/ Bona.pdf

Bonaudo, Marta. “Liberales, masones ¿subversivos?”. Revista de Indias LXVII (2007): 403-432.

Bonaudo, Marta. “SSociabilidades que construyen repúblicas? los desafíos de la masonería decimonónica mirados desde algunos espacios santafesinos y entrerrianos”. En Descubriendo la nación: identidades, imaginarios, estereotipos sociales y formas de asociacionismo de los españoles en el Cono Sur de América. Compilado por Elda González y Andrea Reguera. Buenos Aires: Biblos, 2010.

Corbiére, Emilio. La masonería II: tradición y revolución. Buenos Aires: Debolsillo, 2007.

Corbiére, Emilio. La masonería: política y sociedades secretas. Buenos Aires: Debolsillo, 2011.

Cortés, Ivonne. "Masonería y espacio público: El debate en torno a la "escuela atea" en Chile 1872". REHMLAC+ 10, no. 1 (mayo-noviembre 2018): 72-88. https://doi.org/10.15517/ $\underline{\text { rehmlac.v10i1.32839 }}$

Di Stefano, Roberto. "La expulsión de los masones". En Ovejas negras: Historia de los anticlericales argentinos. Buenos Aires: Sudamericana, 2010.

Favaro, Orietta y Morinelli, Marta. "La política y lo político en Neuquén: la política territoriana en el marco del desenvolvimiento económico y social de Neuquén (1884-1955)”. En Historia de Neuquén. Editado por Susana Bandieri, Orietta Favaro, Marta Morinelli, Susana Rodríguez, Gladys Varela y otros. Argentina, Plus Ultra, 1993.

Ferrer Benimeli, José Antonio. "Aproximación a la historiografía de la masonería latinoamericana", REHMLAC 4, no. 1 (mayo -noviembre 2012): 9, https://revistas.ucr.ac.cr/ index.php/rehmlac/article/view/12144/11419González Bernaldo, Pilar. Civilidad y política en los orígenes de la Nación Argentina. Las sociabilidades en Buenos Aires, 1829-1862. Buenos Aires: FCE, 2001.

Lappas, Albicíades. La masonería argentina a través de sus hombres. Buenos Aires: Ediciones masónicas, 1966 [1958].

Lappas, Albicíades. La masonería en la ocupación del desierto. Buenos Aires: Instituto Histórico de la Organización Nacional, 1981.

REHMLAC+, ISSN 1659-4223, vol. 12, no. 2, diciembre 2019 / junio 2020 
Manara, Carla y Fernández, Sonia. "La problemática inmigratoria en Neuquén: españoles e italianos, 1895-1930”. En: Historia de Neuquén. Editado por Susana Bandieri, Orietta Favaro, Marta Morinelli, Susana Rodríguez, Gladys Varela y otros. Buenos Aires: Plus Ultra, 1993.

Mayo, Carlos. "La masonería en crisis (1902-1922)". En Conflictos y Procesos de la Historia Argentina Contemporánea. Buenos Aires: Centro Editor de América Latina, 1988.

Mollés, Dévrig. La invención de la masonería. Revolución cultural: religión, ciencia y exilios. La Plata: EDULP, 2015.

Pozuelo Andrés, Yván. “Migraciones”, en Masonería y Masones. Tomo I. Migraciones. Editado por Ricardo Martínez Esquivel, Pozuelo Andrés y Rogelio Aragón. Ciudad de México: Palabra de Clío, 2017.

Rodríguez, Ana María T. “Quiénes eran los masones pampeanos de principios de siglo XX? Un estudio de su perfil socio ocupacional y sus redes de vinculación”. Ponencia presentada en el Segundo Seminario euro-argentino de historia de las redes masónicas atlánticas, Buenos Aires, 22-23 de mayo 2014. http://www.redalyc.org/pdf/3695/369537363010.pdf

Rodríguez, Ana María T. "Los masones pampeanos de principios del siglo XX: el perfil socio ocupacional y las redes de vinculación de la Logia Luz de La Pampa, General Pico (1909-1914)". Ponencia presentada en las XXII fornadas de Investigación de la Facultad de Ciencias Humanas, Santa Rosa, La Pampa, 10-11 setiembre 2015.

Rodríguez, Ana María T. "Los conflictos en torno a la construcción de una sociedad católica: voces anticlericales en el Territorio Nacional de La Pampa de principios del siglo XX (1896-1934)". En Fronteras disputadas: religión, secularización y anticlericalismo en la Argentina (siglos $X I X y X X)$. Compilado por Roberto Di Stefano y José Zanca. Buenos Aires: Imago Mundi, 2016.

Rodríguez, Ana María T. "Masones en el interior argentino: su funcionamiento, sus redes de vinculación y su disidencia religiosa (1907-1924)”. REHMLAC+ 9, no. 2 (2017): 176-193. https://doi.org/10.15517/rehmlac.v9i2.29481

San Pedro Talabán, María de los Ángeles. "La Masonería en Huelva durante el siglo XX, 1900-1936". Huelva en su historia 3 (1990): 505-602. 